\title{
Do Organisational Innovations Have Impact on Launching New Products on the Market?
}

\author{
Rolando Koren ${ }^{1}$ - Jasna Prester ${ }^{2}$ - Borut Buchmeister1 - Iztok Palčič 1,* \\ 1 University of Maribor, Faculty of Mechanical Engineering, Slovenia \\ 2 University of Zagreb, Faculty of Economics and Business, Croatia
}

The main purpose of this paper is to define which organisational innovation concepts have the more significant impacts when launching new products on the market. We present an overview of 22 organisational innovative concepts used in Slovenian manufacturing companies. The results are based on data from a sample of 89 manufacturing companies, obtained within a European manufacturing survey (EMS). $A$ detailed analysis based on correlation and regression analysis was performed on more frequently used organisational innovative concepts, where we found interdependence between these concepts. There were significant correlations between organisational innovation concepts such as total quality management (TQM) and total productive maintenance (TPM); task integration and total productive maintenance; methods for continuous improvement (CIP) and total productive maintenance. We also found out that the more complex is the product the use of the majority of organisational innovation concepts has a greater impact. The results showed that the use of selected organisational innovative concepts had a positive impact on launching new products on the market. Multiple regression analysis and correlation analysis showed that the organisational innovative concept TQM, task integration, ISO 9000 and CIP had a significant positive impact on launching new products on the market.

Keywords: innovation, organisational innovation, new products, market, survey research

Highlights

- $\quad$ The impact of organisational innovative concepts was researched when launching new products on the market.

- Interdependence is presented between the more frequently used organisational innovative concepts in the Slovenian manufacturing industries.

- Interdependence is presented between the more frequently used organisational innovative concepts and launching new products on the market.

- $\quad$ Results present the impact of individual organisational innovative concepts on launching new products on the market.

- $\quad$ Research was based on a sample of 89 Slovenian manufacturing companies, the data of which were obtained through a European manufacturing survey.

\section{INTRODUCTION}

Innovations have always been considered as important drivers of economic progress and civilisation in general [1]. Companies that do not invest in innovation are entering into their future with a risk of losing their market share. With no innovative thinking companies decline, which certainly reduces their innovative potentials, competitiveness and, consequently, the likelihood for future business success [2]. Therefore, companies have to constantly explore, invent, innovate and create new values, which will ensure the existence and further development [3]. The term "innovation" is still extremely popular. The more common innovations are associated with research and development (R\&D) activities of a new product's development. Numerous studies have proved that increasing investment in $R \& D$ activities leads to innovative products, which enables companies to achieve competitive advantages and greater market shares [4] and [5]. The introduction of new practices into business systems is important for companies in their quests to upgrade their productivity, improve service quality and maintain competitiveness [6].

There are several types of definitions and classifications of innovation. In the earlier 20-th century Schumpeter described different types of innovation, namely: new products, new methods of production, new resources, research of new markets and new ways of organising production and operations [7]. Among numerous classifications of innovative types, one of the more commonly accepted definitions [8] which distinguishes four types of innovation: product innovation, process innovation, marketing innovation, and organisational innovation (OI). OIs are emerging approaches, as they were not recognised as innovations until qualified as such in [8]. According to Camisón and Villar-López [9], OIs currently represent one of the more important and sustainable sources of competitive advantages for businesses but they have not been sufficiently studied, nor has been their impacts on the innovative and financial effects of companies. Read [10] defines OIs as multidisciplinary areas of research; they are dynamic and iterative 
processes of creating, developing, and producing products, services, processes or policies that are new to organisations.

The paper deals with the analysis of OI concepts and their impacts on launching new products on the market. We present the frequent uses of 22 OIs in manufacturing companies. We also present characteristics of companies' products in terms of their complexities and their relationships with the more frequently used OIs. Given that today innovations are a key competitive tool [11], the aim is to identify those OIs that have the greatest impact on launching new products on the market. Regression and correlation analysis were performed to evaluate how the more frequently used OIs influence each other. Regression analysis shows how each individual OI concept affects the launching new products on the market as the dependent variable.

\section{LITERATURE REVIEW}

Hong et al. [12], who have studied how our understanding of innovation has developed over the past few decades, say that understanding innovation and the role of innovation in business systems greatly evolved over the years. Gunday et al. [13] claim that innovativeness is one of the fundamental instruments of growth strategies to enter new markets, to increase existing market share and to provide a company with a competitive edge. Mumford argues that with rapid changes in technology, and global competition, the success of many organisations has become more dependent on their abilities to bring innovative products to market [14].

Today, innovations are regarded as a multidimensional issue that can be addressed within several contexts. Keupp et al. [15] made an extensive literature review on innovation management, where when analysing more than 342 papers, they found that there were a low number of papers dealing with the field of non-technical innovation, while the number of papers in the field of product innovation was very high. Camisón and Villar-López [16] also argue that the majority of research on innovation followed a technical focus, concentrating more on product development. Similarly, they concluded that OIs are not researched enough and that their impact on innovation and financial results are not obvious. Armbruster et al. [17] and Palcic et al. [18] claimed that non-technical innovations play an increasingly important role in a better understanding of innovation and its impact on the competitiveness of companies.
They also emphasise that the existing literature on OI is diverse and dispersed or does not yet exist.

There are many definitions on OI and sometimes in the literature they can be found as administrative innovation [19] and [20]. Damanpour and Aravind [21] undertook a major study in which they defined OI as the use of new management and business concepts and practices. They showed an overlap of administrative, organisational and managerial innovations. Currently the most accepted definition is the OECD version, which defines OI as the implementation of a new organisational method within a company's business practices, workplace organisation or external relations. The distinguishing features of OI compared to other organisational changes in a company is the implementation of an organisational method (in business practices, workplace organisation or external relations) that has not been used before in the company, usually suggested or enforced by upper management. OI has a tendency to increase company performance by reducing administrative and transaction costs, improving work-place satisfaction (and thus labour productivity), gaining access to non-tradable assets (such as non-codified external knowledge) or reducing costs of supplies. An example would be an introduction of practices for codifying knowledge by establishing databases of best practices, solutions and other codified knowledge. This knowledge is thus more easily accessible to others in the company. Another example might be introduction of training programme for employee developments, improved employee retention by better working conditions, or the initiation of supplier development programmes [8].

Crossan and Apaydin [22] concluded on the basis of a comprehensive meta-analysis that the papers on the topic of OI are narrowly focused. Different groups of OI concepts lead to different objectives. The current literature does not specify which OI contributes to which sources of competitiveness and measures of competitiveness. Perhaps that is one of the reasons why scholars neglect OI as the success of the innovative process is rather difficult to measure. Wright et al. [23] went even further and claimed that managerial and organisational innovations are not really innovations and can be in fact highly standardised. According to Jin et al. [24] only a few studies have examined the relationship between innovative types and company performance, especially within the field of OI. However Gunday et al. [13] proved that teamwork and quality management systems, which fall within the domain of organisational work, ultimately lead to higher financial performance. 
Delarue et al. [25] came to similar conclusions and showed that teamwork improves organisational performance. Jiménez-Jiménez and Sanz-Valle [26] proved that organisational learning (which falls into the domain of human resources management) does in fact lead to greater innovation and business performance. Bolivar-Ramos et al. [27] showed that organisational learning and $\mathrm{OI}$, as competencies and strategic capabilities, can have positive effects on improving organisational performance. Mol and Birkinshaw [6] found that management innovation (another term for OI) is positively associated with company performance in the form of subsequent productivity growth. Evangelista and Vezzani [28] proposed a model showing that OI influences sources of competitiveness such as product performance and efficiency, ultimately leading to higher market share and financial results. However, they tested correlations between sources of innovation rather than testing OI on sources of competitiveness. Laforet [29] found that OI usage results in enhanced productivity, margin, market leadership, and working environments but does not lead to operational efficiency and employees' retention. Hamel [30] argued that OI should have a positive impact on competitive advantage. Prester and Bozac [20] found that usage of some organisational practices, such as interdisciplinary teams, quality circles, system for collection of employees' proposals, planned job rotation, significantly lead to innovation.

As we found very few studies on how OIs are interrelated with new product development [11] and [24], we investigated the more frequently used OI practices in Slovenian manufacturing companies and examined if they had an impact on launching new products on the market.

\section{METHODOLOGY}

Survey method research was used for collecting data in this study. The data was obtained within the largest European research on manufacturing activities, the European manufacturing survey (EMS). The coordinator of the project is the Fraunhofer ISI Institute from Germany. EMS covers indicators within the areas of technical and organisational innovation, relocating of production, energy issues, human resource issues etc. It also covers the future competitive priorities of the company, characteristics of the production process and the characteristics of the company's core product, and innovation issues measured in terms of generated profits by significantly improved products that are new to the company and new products that are new to the market. The target group are companies from the manufacturing sector with more than 20 employees. The first EMS survey in Slovenia was carried out in 2004. It was repeated in the years 2007, 2010 and 2013. The questionnaire has 20 sections and it is eight pages long.

The study includes 22 OI concepts, divided into 4 groups: Organisation of production (6), Organisation of work (5), Standardisation and conformity assessment (6), and Human resource management (5). Companies had to reveal information about the degree of OI use in terms as low use (first contact with the concept), medium use (partial use of the concept) and high use (full application of the concept - at least $70 \%$ of employees are involved in the OI concept).

In 2012791 questionnaires were sent out and 89 responses were returned, representing $11.25 \%$ response rate. Companies that completed the questionnaire in 2013 were $29.2 \%$ small companies, $44.9 \%$ medium-sized and $25.8 \%$ large companies in terms of the number of employees.

Product complexity was divided into simple products, medium-complex products (e.g. pumps, several parts and technologies using simple assembly) and complex products (machines or manufacturing systems). The results showed that the majority of companies (around $52 \%$ ) manufactured mediumcomplex products. A little over a third of companies (36\%) produced complex products and the remaining companies produced simple products. This analysis started with descriptive statistics in which the results of usage of OI were shown, followed by correlation and regression analysis where the interactions between individual groups of OI concepts and new products were analysed.

\section{RESULTS AND DISCUSSION}

\subsection{Organisational Innovative Concepts Use}

Descriptive statistics are shown in Table 1. Companies were asked which of the selected OI concepts were they using and when it was first introduced. If they are not using a specific OI concept, they were asked if they were considering implementing it in the next three years. Among the top 10 more frequently used OI concepts we found five concepts from the "Organisation of the work" group. Two OI concepts from the "Organisation of production" group and two OI concepts from the "Human resources management" group from among the more frequently used concepts and only one OI concept from the "Standardisation and assessment" group. Teamwork in production and assembly was considered as the more widespread 
Table 1. Usages of Ol in Slovenian manufacturing companies

\begin{tabular}{|c|c|c|c|c|c|}
\hline \multicolumn{2}{|c|}{ Organisational concepts } & \multirow{2}{*}{$\begin{array}{c}\text { Fist introduction } \\
\text { (on average) }\end{array}$} & \multirow{2}{*}{$\begin{array}{c}\text { Share [\%] } \\
13.5\end{array}$} & \multirow{2}{*}{$\begin{array}{c}\text { Rank } \\
19\end{array}$} & \multirow{2}{*}{$\begin{array}{c}\begin{array}{c}\text { Share of use } \\
\text { until } 2015[\%]\end{array} \\
10.1\end{array}$} \\
\hline \multirow{6}{*}{$\begin{array}{l}\text { Organisation } \\
\text { of production }\end{array}$} & Value Stream Mapping & & & & \\
\hline & Customer-oriented cell / line & 2002 & 28.1 & 11 & 3.4 \\
\hline & Zero stock principle & 2005 & 27.0 & 12 & 7.9 \\
\hline & Single-minute exchange of die (SMED) & 2003 & 19.1 & 14 & 4.5 \\
\hline & Total Productive Maintenance (TPM) & 2003 & 49.4 & 6 & 5.6 \\
\hline & Total Quality Management (TQM) & 2002 & 40.4 & 8 & 10.1 \\
\hline \multirow{5}{*}{$\begin{array}{l}\text { Organisation } \\
\text { of work }\end{array}$} & Method of $5 \mathrm{~S}$ & 2004 & 52.8 & 4 & 5.6 \\
\hline & Standardised work instructions & 2000 & 77.5 & 2 & 3.4 \\
\hline & Task integration & 2001 & 40.4 & 8 & 3.4 \\
\hline & Met. for cont. process improvement (CIP) & 2004 & 43.8 & 7 & 3.4 \\
\hline & Teamwork in production and assembly & 2000 & 78.7 & 1 & 2.2 \\
\hline \multirow{6}{*}{$\begin{array}{l}\text { Standardisation } \\
\text { and assessment }\end{array}$} & Visual display of process and equip. status & 2005 & 25.8 & 13 & 4.5 \\
\hline & ISO 9000 and other & 2000 & 77.5 & 2 & 4.5 \\
\hline & 6 Sigma & 2007 & 14.6 & 18 & 6.7 \\
\hline & ISO 14001 & 2004 & 16.9 & 17 & 9.0 \\
\hline & IS0 50001: 2011 & 2009 & 2.2 & 21 & 6.7 \\
\hline & Total cost of ownership (TCO) & 2008 & 5.6 & 20 & 7.9 \\
\hline \multirow{5}{*}{$\begin{array}{l}\text { Management of } \\
\text { human resources }\end{array}$} & Formalized workshops to generate ideas & 2003 & 34.8 & 11 & 4.5 \\
\hline & Instruments for retention of knowledge & 2000 & 18.0 & 15 & 9.0 \\
\hline & $\begin{array}{l}\text { Part-time dedicated to creativity } \\
\end{array}$ & 2005 & 18.0 & 15 & 5.6 \\
\hline & Program of staff development & 2004 & 39.3 & 10 & 9.0 \\
\hline & Training to enhance creativity & 2002 & 52.8 & 4 & 5.6 \\
\hline
\end{tabular}

method of organising work, as more than $78 \%$ of Slovenian manufacturing companies used it. The only other two OI concepts with high shares of use were standardised work instructions and implementation of ISO 9000 standards; both of them being present in more than $77 \%$ of manufacturing companies.

It is worth mentioning two more concepts, which are implemented in more than half of Slovenian manufacturing companies namely the concept of the method of $5 \mathrm{~S}(52.8 \%)$ from the "Work organisation" group and concept training to enhance creativity $(52.8 \%)$ from the "Human resource management" group. The other OI concepts are implemented in less than $50 \%$ of Slovenian manufacturing companies. As we can see in Table 1, Slovenian manufacturing companies have been using OI concepts for quite some time and they are not something new for the companies. This is in line with the findings of several authors [23] and [31] to [33] that OI in the business environment have been present for a long time.

For further analysis we have selected OI concepts used in at least $30 \%$ of companies, meaning that we only selected 10 of the more frequently used OI concepts. Firstly, we have looked at degree of using the selected OI. The analysis shows that only the ISO 9000 concept is highly used in more than $50 \%$ of the manufacturing companies. Only one tenth of the companies considered the use of ISO 9000 concept as low. The share of all other highly used OI concepts in companies is less than $50 \%$, where the medium use of $\mathrm{OI}$ is more dominant ranging from $38 \%$ to $62 \%$. The lowest shares of the highly used concepts are linked to the management of human resources (staff development programmes $22.9 \%$ and training of employees $12.8 \%$ ).

\subsection{Organisational innovative Concepts, Product Complexity and New Product Launching}

We also analysed how product complexity depends on the frequency of use of the 10 more widely used OIs. Fig. 1 presents the average shares of selected OI concepts - lower black bar within each OI. The three bars above it represent the share of products based on their complexities within companies that had implemented specific OI (complex, medium complex and simple products). For example, teamwork in production and assembly was considered as the most widespread OI concept, as more than $78 \%$ of companies were using it. Fig. 1 shows that $43.3 \%$ companies with implemented teamwork concept in production and assembly produce complex products. 


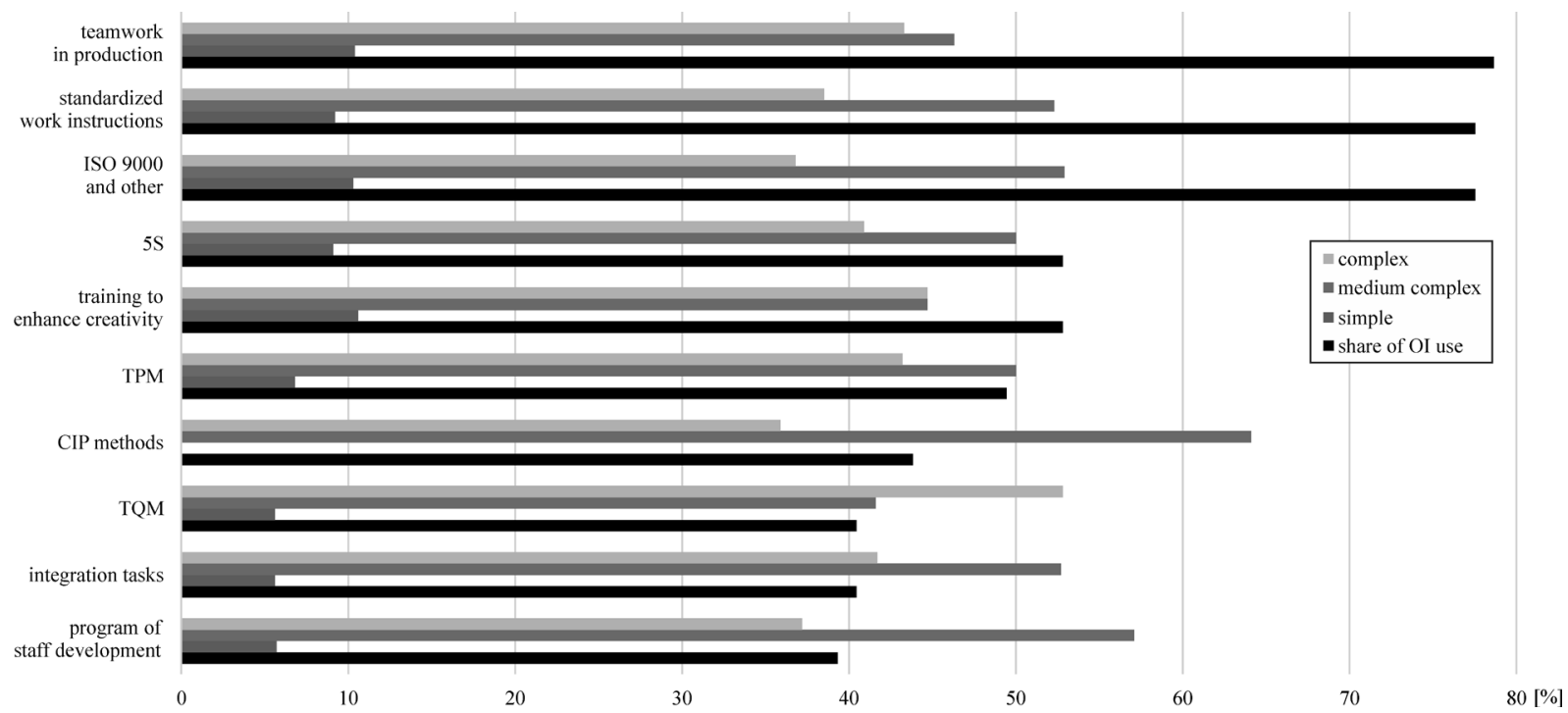

Fig. 1. Characteristic of the product complexity depending on the level of use for the 10 most widely used 0 I

The share of medium-complex products was $46.3 \%$, while the share of simple products was $10.4 \%$. It has already been mentioned that on average $36 \%$ of manufacturing companies produced complex products and $52 \%$ medium complex products. Fig. 1 shows that the share of complex products in companies that implemented analysed OI concepts was higher than usual (36\%) for the majority of OI concepts.

The highest share of complex products $(52.8 \%)$ was produced by companies, with OI concept TQM implemented within their operating systems. They are followed by companies with the implemented concept of training to enhance creativity (44.7\%). Surprisingly, in the penultimate place was the OI concept ISO 9000 and other standards (36.8\%) which were ranked as second in the share of use of the concept in companies. We can assume that the standardisation of systems does not affect the complexities of the products that companies produce. On the other hand, we can observe that the share of simple products was lower within companies that use selected OI concepts - the average share in general was $12 \%$. Share of simple products is especially low in companies that implemented TPM, TQM, integration of tasks, and programmes of staff development. The most interesting was the CIP concept - companies with this OI concept implemented do not produce simple products and where medium complex products were prevalent with almost $65 \%$. Therefore, it can be concluded that the more complex was the product, selected OI have greater impact.
In the period from 2009 until 2012, 61.8\% of Slovenian manufacturing companies had launched a new or significantly improved product on the market, while $22.5 \%$ of companies had introduced radically new products - products that were also new for the market.

Fig. 2 shows the 10 more frequently used OI concepts and their effects on the introductions of new products on the market. On average companies that implemented OI concepts, achieved a higher share of new products launched on the market. The exceptions are two OI concepts namely, method $5 \mathrm{~S}$ and training to enhance creativity, where it can be seen that implementation of these two concepts did not have a specific impact on the introduction of new products on the market.

The biggest difference in the launch of new products on the market (if concepts are introduced and used), can be observed in the use of TQM, task integration and ISO 9000 and other standards. $86 \%$ of companies that implemented TQM in the period from 2009 until 2012 have launched new products on the market. According to the results presented in Fig. 1 it can be concluded that a significant number of new products were in fact complex product launches. By contrast, in the same period only $45 \%$ of companies that did not use TQM launched new products on the market. If companies used task integration on average $81 \%$ of them launched new products on the market. Only $49 \%$ of companies that do not use task integration launched a new product. In the case of ISO $9000,68 \%$ of companies that used ISO 9000 


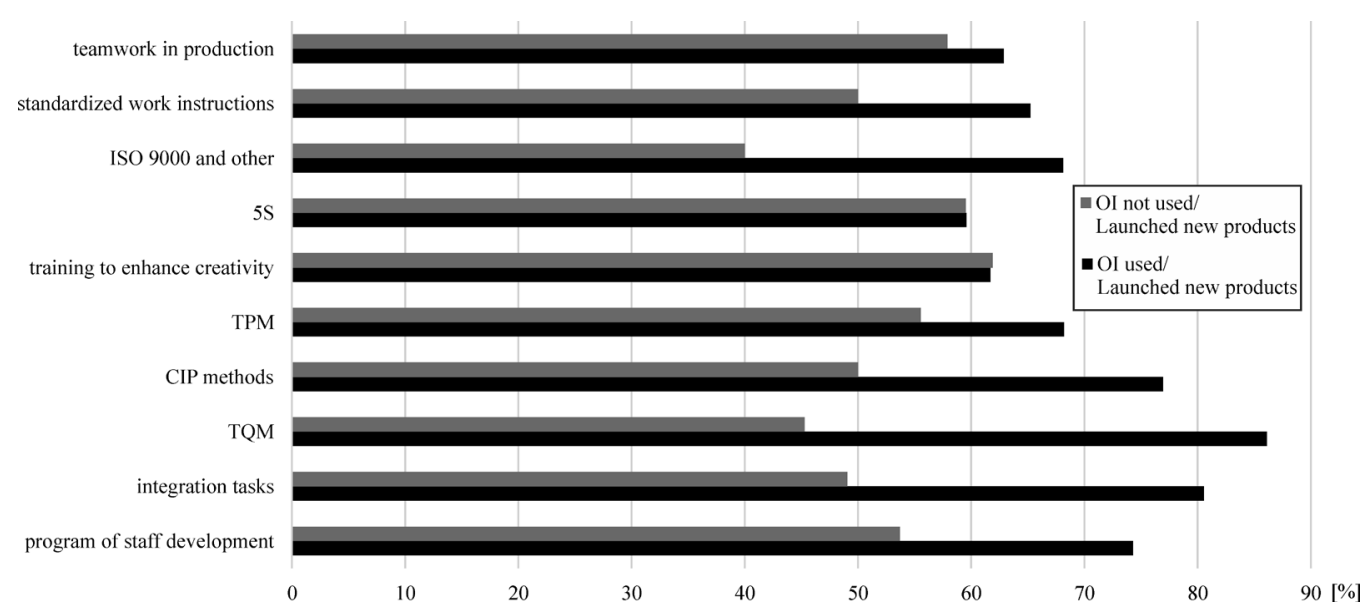

Fig. 2. Share of launched products on the market in relation to the use of the $\mathrm{OI}$

launched a new product on the market but only $40 \%$ of companies that do not use this concept.

Even though we can observe the difference regarding the launch of new products between companies that have implemented OI concepts and those that did not (Fig. 2), we tested whether there was a statistically significant difference. The test showed a statistically significant difference at $\mathrm{P}$-value of 0.05 . Next the correlation analysis between $10 \mathrm{OI}$ concepts was performed to see how they affected each other (Table 2). The analysis showed that some concepts were complementary to each other. There was a high significant correlation between TQM, task integration, CIP and TPM. Investing in TQM, task integration, CIP will lead to higher usage of TPM. An increase in investment in task integration will have a positive impact on TPM, standardised and detailed work instruction teamwork in production, and ISO 9000. So if we invest into forming such a set of OI practices, we can expect enhancements in the mentioned areas. There was a very high correlation between TQM and task integration. This can be explained by the fact that TQM uses quality circles, where employees in the circles perform more tasks, motivating them to see the whole process of the work that can ultimately lead to more innovation. There is also a high correlation between OI concepts ISO 9000 and TPM. This is due to the fact that ISO standards require that all processes in the company are written and accurate. As ISO standards have to be renewed every three years that forces companies to comply with ISO prescriptions and one of them is regularly checking the equipment. Concept employee training for creativity and innovation has a positive impact on concept standardised and detailed work instructions. With newly acquired skills, workers introduce

Table 2. Correlations between the 10 more widely used Ol concepts in Slovenian manufacture companies

\begin{tabular}{|c|c|c|c|c|c|c|c|c|c|c|}
\hline & $\begin{array}{l}\text { Team- } \\
\text { work }\end{array}$ & $\begin{array}{c}\text { ISO } \\
9000\end{array}$ & SDWI & $5 S$ & $\mathrm{ETCl}$ & TPM & CIP & $\mathrm{TI}$ & TQM & TDP \\
\hline Teamwork in production & 1 & & & & & & & & & \\
\hline ISO 9000 and other standards & 0.017 & 1 & & & & & & & & \\
\hline $\begin{array}{l}\text { Standardised and detailed work } \\
\text { instruction (SDWI) }\end{array}$ & $* * 0.319$ & $\star \star 0.277$ & 1 & & & & & & & \\
\hline Method of $5 S$ & 0.189 & 0.129 & $\star \star 0.390$ & 1 & & & & & & \\
\hline $\begin{array}{l}\text { Employee training for creativity } \\
\text { and innovation (ETCl) }\end{array}$ & $\star 0.278$ & *0.274 & **0.303 & *0.224 & 1 & & & & & \\
\hline Total Productive Maintenance (TPM) & *0.255 & $\star * 0.405$ & $\star * 0.336$ & $\star \star 0.361$ & $\star 0.232$ & 1 & & & & \\
\hline $\begin{array}{l}\text { Methods for continuous improvement } \\
\text { process (CIP) }\end{array}$ & $* * 0.342$ & *0.267 & *0.246 & 0.185 & 0.112 & $\star \star 0.404$ & 1 & & & \\
\hline Task integration (TI) & $\star * 0.312$ & ${ }^{\star *} 0.291$ & ${ }^{\star *} 0.390$ & $\star 0.217$ & 0.198 & $\star \star 0.466$ & $\star \star 0.314$ & 1 & & \\
\hline Total Quality Management (TQM) & 0.192 & $* \star 0.324$ & *0.272 & 0.197 & 0.180 & $\star * 0.624$ & $\star * 0.342$ & $\star * 0.493$ & 1 & \\
\hline Talent development program (TDP) & 0.120 & $\star 0.270$ & $\star * 0.317$ & $* 0.234$ & ${ }^{*} 0.270$ & $\star \star 0.331$ & $* 0.230$ & $* * 0.325$ & $* * 0.303$ & 1 \\
\hline
\end{tabular}

\footnotetext{
* Correlation is significant at the 0.05 level (2-tailed); $\quad * *$ Correlation is significant at the 0.01 level (2 tailed).
} 
Table 3. Correlations between $10 \mathrm{Ol}$ concepts and new products launches

\begin{tabular}{lc}
\hline Correlations & New products \\
\hline Total Quality Management TQM & ${ }^{\star *} 0.380$ \\
\hline Task integration & ${ }^{* *} 0.374$ \\
\hline IS0 9000 and others & ${ }^{* \star} 0.313$ \\
\hline Methods for CIP & ${ }^{* \star} 0.289$ \\
\hline Talent development program & ${ }^{\star} 0.242$ \\
\hline Standardised and detailed work instruction & 0.206 \\
\hline Total Productive Maintenance TPM & 0.156 \\
\hline Teamwork in production & 0.119 \\
\hline Method of 5S & 0.045 \\
\hline Employee training for creativity and innovation & -0.042 \\
\hline
\end{tabular}

innovations to their work environment; consequently, the work instructions will be changed and thus indirectly improves business results.

Finally, we investigated the impacts of the 10 more frequently used OI when launching new products on the market (Table 3 ). The results show that there are four very dominant and significant OI concepts (significant value is 0.01 or less), which have a positive impact on launching new products on the market. These concepts are: TQM, task integration, ISO 9000 and CIP. Statistically speaking companies that implement OI concepts will also achieve better results when launching new products on the market. The aforementioned OI concepts directly contribute to improving the qualities of products and services. That means better/high quality products or service, which for customers is often more important than price.

There was also a positive correlation (significant at 0.05 or less) between the OI concept talent development programme and new products. This can be interpreted that companies which invest in staff education and training develop more new products. Other positive effects but insignificant are: standardised and detailed work instruction, TPM, teamwork in production and method of 5S. However, there was one OI concept that had negative effects on launching new products: employee training for creativity and innovation. Statistically speaking increased investment in the aforementioned OI concept resulted in a decrease in newly launched products. However this concept was introduced in companies usually as a prime concept to teach employees innovative thinking, and in order to generate more new ideas for new products. This might be explained by the fact that teaching employees takes time, and consequently there is a time lag between teaching and the actual creating of new products. That might be the reason that a particular concept has a negative effect on launching new products on the market.

Finally, a multi regression analysis was performed, with new products as the dependent variable and selected OI's as independent variables in order to test how each selected OIs influences new product launch (Table 4). Multiple regression analysis yields the standardised regression coefficients which showed the change in the dependent variable measured in standard deviations.

Beta coefficients are the estimates resulting from regression analysis and standardised so that the variances of the dependent and independent variables are equal to 1 . Therefore, standardised coefficients

Table 4. Results of the regression analysis

\begin{tabular}{|c|c|c|c|c|c|c|}
\hline R Square & & Adjusted R Sq & & \multicolumn{2}{|c|}{ Std. Error of the Estimate } & Sig. \\
\hline 0.573 & & 0.227 & & 0.419 & & 0.002 \\
\hline \multirow[t]{2}{*}{ Coefficients (a) } & \multicolumn{2}{|c|}{ Unstandardized Coefficients } & \multirow{2}{*}{\multicolumn{2}{|c|}{$\begin{array}{c}\text { Standardized Coefficients } \\
\text { Beta } \\
\end{array}$}} & \multirow{2}{*}{$\begin{array}{l}t \\
\mathrm{~B}\end{array}$} & Sig. \\
\hline & B & Std. Error & & & & Std. Error \\
\hline (Constant) & 0.329 & 0.154 & & & 2.140 & 0.036 \\
\hline Teamwork in production & 0.027 & 0.137 & & 0.024 & 0.200 & 0.842 \\
\hline ISO 9000 and other standards & 0.197 & 0.138 & & 0.173 & 1.428 & 0.158 \\
\hline Standardized and detailed work instruction & 0.069 & 0.138 & & 0.060 & 0.499 & 0.619 \\
\hline Method of $5 S$ & -0.044 & 0.110 & & -0.047 & -0.402 & 0.689 \\
\hline Employee training for creativity and innovation & -0.197 & 0.109 & & -0.208 & -1.808 & 0.075 \\
\hline Total Productive Maintenance TPM & -0.267 & 0.144 & & -0.282 & -1.856 & 0.068 \\
\hline Methods for CIP & 0.128 & 0.112 & & 0.135 & 1.148 & 0.255 \\
\hline Task integration & 0.205 & 0.122 & & 0.214 & 1.678 & 0.098 \\
\hline Total Quality Management TQM & 0.330 & 0.138 & & 0.346 & 2.385 & 0.020 \\
\hline Talent development program & 0.172 & 0.116 & & 0.178 & 1.484 & 0.142 \\
\hline
\end{tabular}

a. Dependent Variable: New products 
refer to how many standard deviations a dependent variable will change, per standard deviation increase in the independent variable [24]. If we look at the results of the researched model (which is significant) it can be seen that only TQM has a strong significant positive impact on new product launches. TQM with continuous efforts to raise the quality of products or services directly contribute to launch more new products. That coincides with the Santos-Vijande and Álvarez-González study [11] in which they found that TQM and CIP, which are both OIs, have a strong positive impact on new product launches because TQM focuses (among other focuses) on the customer needs and wants, and CIP also gives rise to new modifications in products and processes. Maybe the best example of how CIP, TQM and quality circles improve products and processes can be found in Spear and Bowen [34]. ISO 9000 and others also positively influence new product launches, which might be explained by the fact that ISO manuals have a chapter on guidance for improvements. The method of 5S, employee training for creativity and innovation, and TPM have a negative impact on new product launches - but these concepts give results only in the long-run and that might be the reason why they negatively affect new product launches. On the other hand method of 5S and TPM are indirectly related to innovation rather taking care of the work environment as well as taking preventive care of machines. It must also be noted that these negative influences are small and insignificant. The model shows good correlation $(r=0.573)$ and changes in independent variable will influence change in dependent variable (new product launch) by $33 \%$.

\section{CONCLUSION}

The purpose of this paper was to examine which OI concepts in the Slovenian manufacturing companies have the more significant impact on launching new products on the market. Analysis of the impact of the implementation of OI has shown that companies that implemented OI concepts within their systems are achieving higher shares of launching new products on the market. Regression analysis showed that especially TQM significantly increases new product launches. At the same time correlation analysis for the 10 more widely used OI concepts in the Slovenian manufacturing industry was performed and showed strong significant relationships among OI concepts, showing that for example investing in TQM practices will enhance other OI concepts.
This research has also practical and managerial implications. Our results show that the use of specific OI concepts clearly positively affects the ability to manufacture complex products and the ability to develop, manufacture and launch new product on the market. This is a clear message to managers that technical innovation and the use of advanced technologies is not a sufficient requirement to manufacture and introduce new and complex products.

As is the case with all research, some issues have to be taken into account when considering the reliability, significance, and generalities of the results obtained. First, the data is from Slovenia containing 89 companies. Although the sample is not small further research should go towards the direction of a larger sample of more countries with different levels of development and also different strategies (for example low cost strategy).

\section{ACKNOWLEDGMENTS:}

This work was supported by Croatian Science Foundation Grant number 0-1861-2014-3535.

\section{REFERENCES}

[1] Florida, R. (2005). The Flight of the Creative Class: The New Global Competition for Talent. Harper Collins, New York.

[2] Nagy, T., Ruzzier, M. (2013). Vpliv uporabnikov na proces inoviranja: upravljanje uporabniškega potenciala s strani podjetij. Meritum, Ljubljana.

[3] McGahan, A. (2004). How industries change. Harvard Business Review, vol. 82, no. 6, p. 79-86.

[4] Bikfalvi, A. (2007). Innovation, Entrepreneurship and Outsourcing: Essays on the Use of Knowledge in Business Environments, PhD thesis. University of Gerona, Gerona.

[5] Freeman, C., Soete, L. (1997). The Economics of Industrial Innovation. Pinter Publisher, London.

[6] Mol, M.J., Birkinshaw, J. (2009). The sources of management innovation: When firms introduce new management practices. Journal of Business Research, vol. 62, no. 12, p. 1269-1280, DOI:10.1016/j.jbusres.2009.01.001.

[7] Schumpeter, J.A. (1934). The Theory of Economic Development. An Inquiry into Profits, Capital, Credit, Interest, and the Business Cycle. Harvard University Press, Cambridge.

[8] OECD (2005). The Measurement of Scientific and Technological Activities Oslo Manual. Guidelines for Collecting and Interpreting Innovation Data (3 ed.). OECD EUROSTAT, Paris , DOI:10.1787/9789264013100-en.

[9] Camisón, C., Villar-López, A. (2014). Organizational innovation as an enabler of technological innovation capabilities and firm performance. Journal of Business Research, vol. 67, no. 1, p. 2891-2902, D0I:10.1016/j.jbusres.2012.06.004.

[10] Read, A. (2000). Determinants of successful organizational innovation: Review of current research. Journal of Management Practice, vol. 3, no. 1, p. 95-119. 
[11] Santos-Vijande, M.L., Álvarez-González, L.I. (2007). Innovativeness and organizational innovation in total quality oriented firms: The moderating role of market turbulence, Technovation, vol. 27, no. 9, p. 514-532, D0l:10.1016/j. technovation.2007.05.014.

[12] Hong, S., Oxley, L., McCann, P. (2012). A survey of the innovation surveys. Journal of Economic Surveys, vol. 26, no. 3, p. 420-444, D0l:10.1111/j.1467-6419.2012.00724.x.

[13] Gunday, G., Ulusoy, G., Kilic, K., Alpkan, L. (2011). Effects of innovation types on firm performance. International Journal of Production Economics, vol. 133, no. 2, p. 662-676, DOI:10.1016/j.ijpe.2011.05.014.

[14] Mumford, M.D. (2000). Managing creative people: Strategies and tactics for innovation. Human Resource Management Review, vol. 10, no. 3, p. 313-351, D0l:10.1016/S10534822(99)00043-1.

[15] Keupp, M.M., Palmie, M., Gassmann, 0. (2011). The strategic management of innovation: A systematic review and paths for future research. International Journal of Management Reviews, vol. 14, no. 4, p. 367-390, D0l:10.1111/j.14682370.2011.00321.x.

[16] Camisón, C., Villar-López, A. (2011). Non-technical innovation: Organizational memory and learning capabilities as antecedent factors with effects on sustained competitive advantage. Industrial Marketing Management, vol. 40, no. 8, p. 1294-1304, D0l:10.1016/j.indmarman.2011.10.001.

[17] Armbruster H., Bikfalvi A., Kinkel S., Lay G. (2008). Organizational innovation: The challenge of measuring non-technical innovation in large-scale surveys. Technovation, vol. 28, no. 10, p. 644-657, D0l:10.1016/j. technovation.2008.03.003.

[18] Palčič, I., Buchmeister, B. Polajnar, A. (2010). Analysis of innovation concepts in slovenian manufacturing companies, Strojniški vestnik - Journal of Mechanical Engineering, vol. 56, no. 12, p. 803-810.

[19] Al-Hawari T., Ahmed A., Khrais S., Mumani A. (2013). Impact of assignment, inventory policies and demand patterns on supply chain performance. International Journal of Simulation Modelling, vol. 12, no. 3, p. 164-177, Dol:10.2507/ IJSIMM12(3)3.235.

[20] Prester, J., Bozac, M.G. (2012). Are innovative organizational concepts enough for fostering innovation? International Journal of Innovation Management, vol. 16, no. 1, D0I:10.1142/S1363919611003404.

[21] Damanpour F., Aravind D. (2012). Managerial innovation: Conceptions, processes, and antecedents. Management and Organization Review, vol. 8, no. 2, p. 423-454, Dol:10.1111/ j.1740-8784.2011.00233.x.

[22] Crossan, M.M., Apaydin, M. (2010). A multi-dimensional framework of organizational innovation: A systematic review of the literature. Journal of Management Studies, vol. 46, no. 6, p. 1154-1191, Dol:10.1111/j.1467-6486.2009.00880.x.
[23] Wright, C., Sturdy, A., Wylie, N. (2012). Management innovation through standardization: Consultants as standardizers of organizational practice. Research Policy, vol. 41, no. 3, p. 652662, D0I:10.1016/j.respol.2011.12.004.

[24] Jin, Z., Hewitt-Dundas, N., Thompson, N.J. (2004). Innovativeness and performance: evidence from manufacturing sectors. Journal of Strategic Marketing, vol. 12, no. 4, p. 255-266, Dol:10.1080/0965254042000308075.

[25] Delarue, A., Van Hootegem, G., Procter, S., Burridge, M. (2007). Teamworking and organizational performance: A review of survey-based research. International Journal of Management Reviews, vol. 10, no. 2, p. 127-148, Dol:10.1111/j.14682370.2007.00227.x.

[26] Jiménez-Jiménez, D., Sanz-Valle, R. (2011). Innovation, organizational learning, and performance. Journal of Business Research, vol. 64, no. 4, p. 408-417, D0l:10.1016/j. jbusres.2010.09.010.

[27] Bolivar-Ramos, M.T., Garcia-Morales, V.J., Garcia-Sanchez, E. (2012). Technological distinctive competencies and organizational learning: Effects on organizational innovation to improve firm performance. Journal of Engineering and Technology Management, vol. 29, no. 3, p. 331-357, D0I:10.1016/j.jengtecman.2012.03.006.

[28] Evangelista, R., Vezzani, A. (2010). The economic impact of technological and organizational innovations. A firm-level analysis. Research Policy, vol. 39, no. 10, p. 1253-1263, Dol:10.1016/j.respol.2010.08.004.

[29] Laforet, S. (2013). Organizational innovation outcomes in SMEs: Effects of age, size, and sector. Journal of World Business, vol. 48, no. 4, p. 490-502, Dol:10.1016/j. jwb.2012.09.005.

[30] Hamel, G. (2009). Management Innovation: This is now a door-die management matter. Leadership Excellence, vol. 26, no. 5.

[31] Lai, X.D., Wu, G.-D., Shi, J.G., Wang, H.M., Kong, Q.S. (2015). Project value-adding optimization of project-based supply chain under dynamic reputation incentives. International Journal of Simulation Modelling, vol. 14, no. 1, p. 121-133, D0I:10.2507/IJSIMM14(1)C01.

[32] Gong, D., Liu, S., Lu, X. (2015). Modelling the impacts of resource sharing on supply chain efficiency. International Journal of Simulation Modelling, vol. 14, no. 4, p. 744-755, D0I:10.2507/IJSIMM14(4)C020.

[33] Koren, R., Palčič, I. (2015). The impact of technical and organisational innovation concepts on product characteristics. Advances in Production Engineering \& Management, vol. 10, no. 1, p. 27-39, D0l:10.14743/apem2015.1.190.

[34] Spear, S.J., Bowen, H.K. (1999). Decoding the DNA of the Toyota Production System. Harvard Business Review, no. SepOct, p. 96-106. 